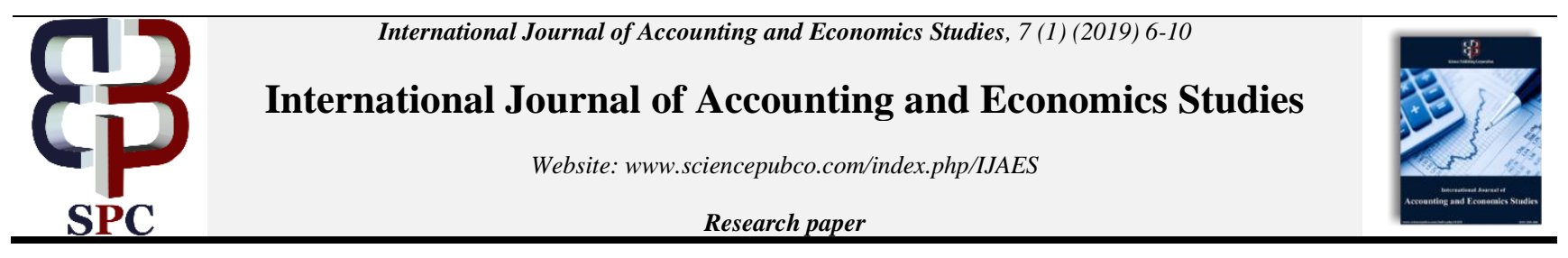

\title{
The impact of information systems disclosures as a part of structural capital on banks' profitably: a case study of Islamic banks in Jordan
}

\author{
Sulaiman Weshah $^{1}$ *, Abdelrazaq Altal ${ }^{2}$, Ziad Obeidat ${ }^{2}$ \\ ${ }^{I}$ Balqa Applied University, Jordan \\ ${ }^{2}$ The World Islamic Science \& Education University, Jordan \\ *Corresponding author E-mail: sulaiman.weshah@bau.edu.jo
}

\begin{abstract}
Aim: This study aimed to show the impact of intellectual capital disclosures related to information systems (IS) on profitability of Islamic banks in Jordan for the years (2013-2017).

Background: Accounting information systems spreading widely because of the speed and accuracy of these technologies in the completion of work. Thus, the study illustrates the impact of intellectual capital disclosures related to information systems (IS) on profitability. Methodology: To achieve study goals an analytic descriptive process was used depended on published data within annual financial reports to study society with sample size reached all Islamic banks in Jordan with (one sample T-Test) and (simple linear regression).

Contribution: The study will be useful to under light the importance of intellectual capital disclosures in general and intellectual capital disclosures related to information systems (IS) and it is impact on profitability.

Findings: The study is revealed that the most important outcome showed there is an impact of intellectual capital disclosure related to information systems (IS) as structural intellectual capital on profitability of Islamic banks in Jordan.

Recommendations to Practitioners: The study recommended continuing and increase declaration about intellectual capital related to information systems.

Recommendations to Researchers: The study recommended with necessity of doing extra studies about the same topic in different field(s). Impact to Society: Society will be recognized the importance of intellectual capital disclosures related to information systems (IS) and it is impact on profitability.
\end{abstract}

Keywords: Intellectual Capital Disclosure; Information Systems; Profitability; Islamic Banks; Jordan.

\section{Introduction}

In the light of the knowledge and information systems (IS) economy and the globalization of information age, the focus on information systems and knowledge means the ability to acquire an important asset which lead to viability, continuity and growth in organizations. Intellectual capital - perceived as a group of skills and knowledge that the organization has to respond to customer requirements and the opportunities offered by technology - is the real capital of organizations as it plays the key role in the process of innovation, creativity, modernization and building competitive advantage that keeps pace with changes in markets (Wen-Ying, 2005).

Because of these continuous changes and the emergence of new challenges, organizations are constantly seeking to develop their operations through R \& D, obtaining patents, building good reputation, reputation and brand by training employees, improving their skills, attracting distinctive skills and skills, building a network of communication with the external environment and gaining satisfaction and loyalty of Clients. These endeavors were later regarded as components of intellectual capital (Al-Tall, 2014).

Financial and non-financial accounting disclosure is the most effective means of communicating information to its users to help them make economic and investment decisions (Jahjouh, 2017), (Orens and Lybaert, 2013) noted that the integrated reporting includes both financial and non-financial information. These reports reflect the company's strategy, performance, and forecasts as a result of the expansion of nonfinancial information, Attention has been paid to the nature of such information, as it provides various assistance to decision makers. (Csorny, 2013) mentioned that employment in IT industry rose quickly, as many businesses began to invest in computer systems. Between 2001 and 2011, employment in computer systems design and related services increased by 232,300 jobs. Where (Kuralová and Margarisová, 2016) focused on the quality of intellectual capital disclosure such as modern management method under structural capital. This lead to take into consideration the information systems (IS) as a modern management method and the impact of intellectual capital disclosure related to information systems (IS) on firm's market value and profitability within informatic age. 


\section{Study questions}

The following questions can form the study problem about what is the impact of intellectual capital disclosure related to information systems (IS) on profitability of Islamic banks in Jordan?

a) What is the level of disclosure of structural intellectual capital related to information systems in the Islamic banks in Jordan?

b) Is there an impact of the disclosure level of structural intellectual capital related to information systems (IS) on profitability of Islamic banks in Jordan?

\section{Review of literature and theoretical background}

\subsection{Intellectual capital}

Intellectual capital has been defined as: "the difference between the market value and the book value of an enterprise, or those resources resulting from internal learning and the development of a relationship of value" (Ahmadi, 2011).

\subsection{Components of intellectual capital}

\subsubsection{Human capital}

It refers specifically to the capabilities, competencies and expertise of human resources (Moghadam et al, 2013). This corresponds to the definition of the skills, abilities and accumulated experience of the human element in the organization. It has been defined as individual contributions by FAO employees to knowledge, ideas, creations, and patents that will increase the value of intangible assets in the organization (Michele and Hanandi, 2013).

\subsubsection{Structural capital}

It refers to organizational knowledge, which is reflected in the processes, procedures and systems used in the organization (Moghadam, 2013), and also includes the functions, techniques, policies and organizational structure (Michele and Hanandi, 2013). The basic focus of human capital is the organization's goals and visions, its organizational concept, its organizational capabilities to meet market requirements, databases, and the quality and accessibility of technical information systems (Mazlan, 2005).

\subsubsection{Customer capital (relational capital)}

It refers to the knowledge and efficiency of the organization through networks of relationships with external parties such as customers, suppliers, partners, industry (Lee \& Liew 2012), (Cricelli et al 2011).

This study focusing on structural capital which includes the systems, data bases and technical information systems (IS) used in the organizations, which are using now a days to improve organizational capabilities to meet market requirements.

\subsection{Disclosure}

The importance of accounting disclosure as one of the key pillars of GAAP and IFRS is recognized as a consistent principle in financial reporting. These principles and standards call for disclosure of all financial and non-financial information to serve all interested parties. The disclosure is defined as providing the accounting information contained in the financial statements and announcing them in a timely manner by following a policy of complete clarity that enables all parties to make appropriate decisions based on this information whether financial or non-financial, in order to serve the interests of the beneficiaries of the reports and financial statements published (Abu Jarad, 2015). The information provided in the annual reports also helps to give an indication of the company's ability to continue and fulfill its social responsibilities that are not measured in cash (Latridis, 2011).

In Jordan, as well as the importance of non-financial disclosure, JSC issued a guide for preparing the annual report of public shareholding companies, through which annual reports contain financial and non-financial information such as general description of the company's activities, geographical locations, Its organizational structure, its competitive position, the risks to which the company may be exposed, the significant events that occurred during the financial year, its future plan, amount of audit fees, information on the board of directors and managers information on the ownership structure (Jordan Securities Commission, 2018), It also applies international standards such as IOSCO principles, corporate governance standards and international auditing standards, as well as monitoring, regulating and developing the Jordanian capital market in the area of securities disclosure and dealing with the development of the Jordanian economy, encouraging investment and protecting investors.

\subsection{Intellectual capital and creating value}

Using new technical information systems considered as one of create value methods for the organizations (Hill \& Jones, 2009).

Structural capital is the infrastructure that serves human capital, and is the systems, laws, procedures, programs and techniques that support the human element to perform its work (Abu Libda, 2008). The role of structural capital is to create value through its ability to improve the production process through methods and means to serve operational processes, thereby reducing production costs and increasing the company's profits (Baqash, 2012).

Wide using of information technology consider as one of major intellectual capital factors create value for organizations (al-fadel, 2009) in banks sector in Gulf area, also (al-Shabani, 2011) considered the higher level of knowledge and technological proficiency, the more likely it will be to reduce the level of costs which is reflect on organization value.

(Chen et al. 2005) depending on ROE and ROA, mentioned there is a strong relation between structural capital and other intellectual capital components with firm's market value parallel with (Day-Yang et al. 2009) study results in Taiwan.

(Mitali and Deepa, 2013) researched the level of intellectual capital for pharmaceutical companies in India and found there is a low level where there was a difficult in measurement of intellectual capital components. 
Studies of (Uyar and Kilic, 2012) in Turkey and (Qin, 2014) in China revealed there is no relation between voluntary disclosure and firm share's market value. But, (Malgharni, 2013) study in Iranian market revealed there is a positive relation between voluntary non-financial disclosure and investor's behavior, while (Grewal et al, 2016) study in Europe markets revealed there is a negative impact of non-financial disclosure on firm's financial performance.

The determinants of the expansion in disclosure process are related to the nature and characteristics of the company such as the size of the company, the nature of its activity, the type of management, the structure of the capital, the volume of sales and profitability (Rouf, 2011). Many studies declared there is a relation between intellectual capital and profitability, such as (Kowalaska, 2015) confirmed a correlation between the Value-Added Intellectual Capital and profitability indicators, pointing to the growing importance of intellectual capital in agricultural enterprises, and (Makki, 2008) declared also that Intellectual Capital has efficiency contributes significantly to the firm's profitability

\subsection{Return on assets (ROA)}

One of the profitability indicators is that the assets are the main sources of the financial position and contribute to increase the rate of profits by employing them to achieve profitability and calculated by dividing the net profit for the year ended on the total of assets.

\section{Study methodology and society}

An analytical descriptive methodology approach adopted in conducting and investigate current study which aims to identify if there is an impact of Structural intellectual capital disclosures related to information systems (IS) on profitability of Islamic banks in Jordan for the years (2013-2017), measured by Return on Assets (ROA) for study society, which include Data analysis, measurement and interpretation. Through that, study aimed to arrive at a precise description of the phenomenon in a comprehensive manner useful in the dissemination of facts or knowledge and helps to a reasonable future prediction of the phenomenon and provide solutions and proposals to be addressed. There are four Islamic banks in Jordan, they are public companies and listed in Amman SEC, which formed the society of this study listed on following (Table1):

Table 1: Islamic Banks in Jordan

\begin{tabular}{ll}
\hline S. N. & Bank Name \\
\hline 1 & Jordan Islamic Bank \\
2 & Islamic International Arab Bank \\
3 & Safwa Islamic Bank \\
4 & Al Rajhi Bank \\
\hline
\end{tabular}

\section{Data analysis}

\subsection{Disclosures level of structural intellectual capital in Islamic banks in Jordan (2013-2017) related to information systems (IS)}

Table 2: Level of Disclosures for Intellectual Capital Related to Information Systems (IS) within Structural Capital for Islamic Banks in Jordan

\begin{tabular}{lllll}
\hline$\%$ & Jordan Islamic Bank & Islamic International Arab Bank & Safwa Islamic Bank & Al Rajhi Bank \\
\hline (IS) Structural capital & 81.45 & 46.33 & 23.14 & 46.45 \\
\hline
\end{tabular}

(Table 2) shows the percentage of disclosure of the structural intellectual capital in Islamic banks in Jordan reached (53.12\%). Jordan Islamic Bank ranked first in terms of disclosure of (IS) intellectual capital components by (81.45\%). In addition, Safwa Islamic Bank ranked last in terms of disclosure of (IS) intellectual capital components by $(23.14 \%)$.

\subsection{Disclosures level of structural intellectual capital related to information systems (IS)}

Table 2: Disclosures Level of (IS) Structural Intellectual Capital

\begin{tabular}{llllllllll}
\hline $\begin{array}{l}\text { Dependent Varia- } \\
\text { ble }\end{array}$ & $\mathrm{R}$ & $\mathrm{R} \mathrm{R}^{2}$ & $\begin{array}{l}\text { Calculated } \\
\mathrm{F}\end{array}$ & $\begin{array}{l}\mathrm{Sig} \mathrm{F}(\alpha \leq \\
0.05)\end{array}$ & $\begin{array}{l}\text { Regression coefficient } \\
\text { Independent Variable }\end{array}$ & $\begin{array}{l}\text { Std Er- } \\
\text { ror }\end{array}$ & $\begin{array}{l}\text { Calcu- } \\
\text { lated }\end{array}$ & $\begin{array}{l}\text { Sig }(\alpha \leq \\
0.05)\end{array}$ \\
\hline Profitability & 0.516 & 0.266 & 6.109 & 0.023 & $\begin{array}{l}\text { (IS) Structured Capi- } \\
\text { tal }\end{array}$ & 1.840 & 0.656 & 2.685 & 0.023 \\
\hline
\end{tabular}

The results of the above table indicate that the effect of the independent variable (the disclosure of (IS) structural capital) on the dependent variable (profitability of Islamic banks in Jordan) is statistically significant, where the calculated F value is (6.109) and the level of significance ( $\operatorname{Sig} F=0.023)$. $(\mathrm{R}=0.516)$ indicates the positive relationship between the two variables.

In addition, the value of the coefficient of determination was $\left(\mathrm{R}^{2}=0.266\right)$, which is indicates that $26.6 \%$ of the variance in profitability of Islamic banks in Jordan can be explained by the difference in the (IS) disclosure of capital with all other variables remaining constant. The regression coefficient $(\beta=1.840)$ indicates the total effect of the disclosure of (IS) structured capital on the profitability of Islamic banks in Jordan, which is a significant effect, where the value of ( $\mathrm{t})$ is (2.431) and the level of significance $($ Sig $=0.023)$.

\subsection{ROA of Islamic banks in Jordan}

Table 3: ROA of Islamic Banks in Jordan for the Years (2013-2017)

\begin{tabular}{lllll}
\hline Bank & Jordan Islamic Bank & Islamic International Arab Bank & Safwa Islamic Bank & Al Rajhi Bank \\
\hline Mean of ROA & 1.304 & 1.242 & 0.344 & 0.246 \\
\hline
\end{tabular}

The average of ROA of Islamic banks in Jordan for the period (2013-2017) reached 0.784. It is important to note that Jordan Islamic Bank ranked first with an average volume of 1.304, where the Al Rajhi bank ranked last with an average of 0.246 . 


\section{Conclusions and recommendations}

Banks now a days are tending to use information systems (IS), which is considered as one of structural intellectual capital inside these banks.

Perhaps the Safwa Islamic Bank, which ranked last in terms of disclosure of (IS) intellectual capital components by (23.14\%), did not ranked last with average in ROA. But it is ROA mean is equal to 0.344, with difference of 0.96 from Jordan Islamic Bank' ROA, which ranked first in terms of disclosure of (IS) intellectual capital components by $(81.45 \%)$.

Information systems (IS) as one of bank's property has a value - intellectual value - which can affect to banks' profitability, that means banks does investing in information systems (IS), this investment will be reflected on banks' profitability.

The study recommends, in general, Islamic banks in Jordan to continue to disclose non-financial information and specially information systems (IS) structural intellectual capital. because they have an impact on raising profitability.

In addition, there is a need to increase investor interest in non-financial disclosure; due to the role of non-financial disclosure to reduce the uncertainties associated with growth opportunities, in addition to provides additional information on future investment opportunities.

Today's researchers on corporations and businesses are presenting information technology (IT) as a factor in the creation of business values in the future and are studying IT and business from the viewpoint of business competitiveness (Lee, 2011).

Thus, for further studies, the study recommends doing extra studies about the same topic in different field(s).

\section{References}

[1] Ahmadi, S.A., Daraei, M.R., and Moghani, A. (2012). Investigation of Intellectual Capital Management Effect on Financial Turnover of the Organization: The Case of Sadid Industrial Group in 2012. IJRMEC, Vol. 2, Issue 12, pp. 32-49.

[2] Abu Lebdah, Hashim Issa (2008), Investment in Intellectual Capital in learning Organization, unpublished master thesis, Al-Albait university, Jordan, Al-Mafarq.

[3] Al-fadel, Mu'aiad Muhammad (2009), Relationship between Intellectual Capital and Creation Value, AL-Qadisiyah Journal For Administrative and Economics Studies, Iraq, V11, 3 .

[4] Ali Uyar, Merve Kılıç, (2012) "Value relevance of voluntary disclosure: evidence from Turkish firms", Journal of Intellectual Capital, Vol. 13 Issue: 3, pp.363-376 https://doi.org/10.1108/14691931211248918.

[5] Al-Shabani, Saleh Ibrahim (2011), Impact of Intellectual Capital on Technology Professionality and Reflection on Cost Reduction: Applied Study on National Furniture Manufacturing Companies, Journal of Anbar University for Economic and Administration Sciences, Iraq, V4, 7.

[6] ALTAL, Abdelrazaq Faleh. The Impact of Intellectual Capital Disclosure on Market Value: An Empirical Study on Jordanian Pharmaceutical Manufacturing Companies Listed in Amman Stock Exchange. Journal of Social Sciences (COES\&RJ-JSS), [S. 1.], v.5, p. 277-290. https://doi.org/10.25255/jss.2016.5.3.277.290.

[7] Baqash, Nadia Omar (2012), The impact of intellectual capital on the performance of manufacturing companies listed on Amman stock exchange, unpublished master thesis, Yarmouk University, Jordan, Irbid.

[8] Charles W. L. Hill \& Gareth R. Jones, (2009), Essentials of Strategic Management, $3^{\text {rd }}$ Edition, South-Western Cengage Learning, 90-94.

[9] Csorny, Lauren (2013), Careers in the growing field of information technology services, U.S. BUREAU of LABOR STATISTICS (BLS), $2,3$.

[10] Cricelli L, Grimaldi M, Levialdi N (2011) The competition among mobile network operators in the telecommunication supply chain, International Journal of Production Economics. 131(1): 22-29. https://doi.org/10.1016/j.ijpe.2010.02.003.

[11] Day-Yang Liu, Kuo-An Tseng, Szu-Wei Yen, (2009) "The incremental impact of intellectual capital on value creation", Journal of Intellectual Capital, Vol. 10 Issue: 2, pp.260-276 https://doi.org/10.1108/14691930910952650.

[12] Jahjouh, Mohammad Majed, (2017), The impact of non-financial disclosure on the market value of companies listed on the Palestine Stock Exchange, Master thesis, Islamic University, Palestine, Ghaza.

[13] Jordan Securities Commission publishes, 2018.

[14] Hong Joo Lee (2011), Analysis of Business Attributes in Information Technology Environments, Journal of Information Processing Systems, Vol.7, 2, 385:396. https://doi.org/10.3745/JIPS.2011.7.2.385.

[15] Iatridis, George., (2011). Accounting Disclosures, Accounting Quality, Conditional, and Unconditional Conservatism, International Review of Financial Analysis, 2(2), 88- 102. https://doi.org/10.1016/j.irfa.2011.02.013.

[16] Kowalska, Magdalena Kozera (2015), The Impact of Intellectual Capital Efficiency on the Profitability of Agricultural Enterprises, Conference Paper · March 2015

[17] Kateřina Kuralová and Klára Margarisová, (2016), INTELLECTUAL CAPITAL DISCLOSURE AT CZECH PUBLIC UNIVERSITIES IN RELATION TO THE STAKEHOLDER INFORMATION NEED, ACTA UNIVERSITATIS AGRICULTURAE ET SILVICULTURAE MENDELIANAE BRUNENSIS, Volume64, 1989-1998. https://doi.org/10.11118/actaun201664061989.

[18] Lee C, Liew KC (2012) Modelling and Risk Management in the Offshore and Marine Industry Supply Chain. Int. J. Eng. Bus. Manag. 4(1): 1-7. https://doi.org/10.5772/45738.

[19] Michele Grimaldi and Musadaq Hanandi, (2013), Evaluating the Intellectual Capital of Technology Transfer and Learning Public Services, International Journal of Engineering Business Management, Vol. 5, 1-10. https://doi.org/10.5772/56002.

[20] Ming-Chin Chen, Shu-Ju Cheng and Yuhchang Hwang (2005), An Empirical Investigation of the Relationship between Intellectual Capital and Firms' Market Value and Financial performance, Journal of Intellectual Capital Vol. 6 No. 2, pp. $159-176$ https://doi.org/10.1108/14691930510592771.

[21] Mitali Sen \& Deepa Sharma, 2013. "Intellectual Capital Disclosure of Select Pharmaceutical and Software Companies in India," The IUP Journal of Accounting Research and Audit Practices, IUP Publications, vol. 0(1), pages 47-62.

[22] Malgharni, A., Wan, Y., Wan, F. (2013). The Effect of Disclosure of Non - Financial Performance Indicators on Stock Price Estimate in Iran. Australian Journal of Basic and Applied Sciences. 7(4), 563 - 574

[23] Makki, Abdul Majid (2008), Impact of Intellectual Capital Efficiency on Profitability (A Case Study of LSE25 Companies), The Lahore Journal of Economics, 13: 2 (Winter 2008): pp. 81-98 https://doi.org/10.35536/lie.2008.v13.i2.a5.

[24] Orens, R and Lybaret, N, (2013), Does the Financial Analysts Usages of Non-Financial Information influence the Analysts Forecast accuracy? Some Evidence from The Belgian Sell-Side Financial Analyst, The International Journal of Accounting ,42 (3), 237-271 https://doi.org/10.1016/j.intacc.2007.06.002.

[25] Qin, T. (2014). Voluntary Disclosure of Listed Chinese Companies 2008-2012: An Empirical Study (Thesis, Master of Management Studies (MMS)) University of Waikato, Hamilton, New Zealand.

[26] Rajab, Abu Jarad, (2015), The relationship between the reservation in the accounting policies and the institutional governance and its impact on the quality of disclosure of the financial statements of local banks listed on the Palestine Stock Exchange, Master thesis, Islamic University, Palestine, Ghaza.

[27] Rouf, A. 2011. Corporate characteristics, governance attributes and the extent of voluntary disclosure in Bangladesh. African Journal of Business Management,5,7836-7845. https://doi.org/10.5897/AJBM10.1180. 
[28] S. Khayat Moghadam1, M. R. Zabihi1, M. Kargaran, A. Hakimzadeh, (2013), Intellectual Capital and organizational learning capability, Journal of Soft Computing and Applications, 1-9. https://doi.org/10.5899/2013/jsca-00011.

[29] Wen-Ying Wang, Chingfu Chang, (2005) "Intellectual capital and performance in causal models: Evidence from the information technology industry in Taiwan", Journal of Intellectual Capital, Vol. 6 Issue: 2, pp.222-236. https://doi.org/10.1108/14691930510592816. 